\title{
Pharmacogenomics, Pharmacokinetics and Circulating Proteins As Biomarkers for Bevacizumab Treatment Optimization in Patients with Cancer: A Review
}

\author{
Apostolos Papachristos * and Gregory B. Sivolapenko \\ Laboratory of Pharmacokinetics, Department of Pharmacy, School of Health Sciences, University of Patras, \\ 26504 Patras, Greece; gsivolap@upatras.gr \\ * Correspondence: alkispapachristos@gmail.com; Tel.: +30-26-1096-2324
}

Received: 10 July 2020; Accepted: 30 July 2020; Published: 4 August 2020

\begin{abstract}
Bevacizumab is a monoclonal antibody that targets VEGF-A and inhibits tumor angiogenesis. Bevacizumab is approved for the treatment of various cancer, including metastatic colorectal cancer (mCRC), ovarian cancer, lung cancer, and others. Thus, it is widely used in oncology, but contrary to other therapeutic classes, there is still a lack of validating predictive factors for treatment outcomes with these agents. In recent years, the research for factors predictive of anti-VEGF treatments and especially bevacizumab response has been one of the most competitive translational research fields. Herein, we review and present the available literature of the clinical use of biomarkers, pharmacogenomics (PG), and therapeutic drug monitoring (TDM) approaches that can be used for the optimization of bevacizumab use in the era of precision medicine.
\end{abstract}

Keywords: bevacizumab; pharmacogenomics; pharmacokinetics; anti-angiogenetic therapy; biomarkers; therapeutic drug monitoring; VEGF-A; precision medicine

\section{Introduction}

In 1971, Judah Folkman described first the process of angiogenesis and its contribution to tumor growth [1]. Since then, angiogenesis pathway has been extensively studied. The dominant factor controlling angiogenesis is a glycoprotein called vascular endothelial growth factor (VEGF) [2-4]. Several studies have highlighted the prognostic and predictive significance of VEGF and VEGFR in colorectal [5,6], lung [7,8], gastric [9], and pancreatic cancers [10]. Thus, angiogenesis and especially VEGF-A have become attractive pharmacologic targets. Bevacizumab, a recombinant humanized IgG1 monoclonal antibody, binds to circulating VEGF-A and the blocking of VEGF-A, which results in the inhibition of tumor angiogenesis, growth, and metastases [11].

In Europe and the USA, bevacizumab has been approved as monotherapy or in combination with chemotherapy and in various dosage regimens for the treatment of metastatic colorectal cancer ( $\mathrm{mCRC})$, metastatic breast cancer $(\mathrm{mBC})$, unresectable advanced, metastatic or recurrent non-small cell lung cancer (NSCLC), advanced or metastatic renal-cell cancer (RCC), advanced, recurrent glioblastoma, advanced ovarian, and cervical cancers $[12,13]$.

Most of these approvals are based on improvements in progression-free survival (PFS), not overall survival (OS) [14,15]. Firstly, in mBC, all five major randomized phase III trials (AVF2119g, E2100, AVADO, RIBBON-1, and RIBBON-2) revealed no significant increase in OS [16]. Similarly, phase III trials did not find any significant benefit in ovarian cancer (GOG-0218, ICON7, AURELIA, and OCEANS), metastatic RCC (AVOREN and CALGB 90206), glioblastoma (AVAglio and TROG 0825), NSCLC (AVAiL and BeTa) [14]. Moreover, no OS benefit was observed in five of seven mCRC trials 
(NO16966, NSABP C-08, ML18147, and MAX) [14]. However, the product continues to be widely used. Since its first approval in 2004, bevacizumab has generated sales of more than $\$ 50$ billion in drug costs alone, which represents a financial burden on healthcare systems worldwide [14,15].

Besides, contrary to other therapeutic classes in oncology, there is still a lack of validating predictive factors for treatment outcomes with bevacizumab. The ability to use therapy towards well-selected subgroups of patients would increase the likelihood of benefits and would improve cost-effectiveness and therapeutic outcomes. In recent years the research for factors predictive of anti-VEGF treatments and especially bevacizumab response has been one of the most competitive translational research fields. Herein, we review the available literature and further delve into the identification, and the clinical use of proteinic and genetic-pharmacogenomic biomarkers, as well as therapeutic drug monitoring (TDM) approaches that can be used for the optimization of bevacizumab use in the era of precision medicine.

\section{Proteinic Biomarkers}

The measurement of concentrations of circulating proteins is an attractive biomarker strategy, as blood is easily accessible, the assays are inexpensive, and the proteins may be readily and quantitatively measured by automated methods such as enzyme-linked immunosorbent assays (ELISA). Proteins have been assessed as potential predictive biomarkers in $\mathrm{mBC}, \mathrm{mCRC}$, lung cancer, ovarian cancer, RCC, and glioblastoma.

\subsection{Metastatic Breast Cancer (mBC)}

Burstein $\mathrm{HJ}$ et al. sought to determine the efficacy and safety of bevacizumab and vinorelbine and to explore the role of baseline plasma VEGF-A as a predictor of treatment outcome. Levels $>32.6 \mathrm{pg} / \mathrm{mL}$ were significantly associated with a shorter PFS $(p=0.003)$ [17]. AVF2119g trial the effect of capecitabine or capecitabine plus bevacizumab. Primary tissue samples were examined for biomarkers discovery. The panel included VEGF-A, VEGF-B, thrombospondin-2 (THBS-2), Flt4, VEGF-C, Platelet-derived growth factor C (PDGF-C), neuropilin-1, delta-like ligand D114, Bv8, p53, and thymidine phosphorylase. Of them, VEGF-A expression showed a predictive significance $(p=0.01)$ for improved PFS when bevacizumab was added [18] (Table 1).

\subsection{Metastatic Colorectal Cancer ( $m C R C)$}

A pivotal study in 813 patients, who received a combination of IFL and bevacizumab or placebo, assessed the expression of the stromal and epithelial VEGF-A, THBS-2 score, and microvessel density (MVD) in tissue samples. No biomarker associated with survival [19]. Plasma samples from HORIZON III (mFOLFOX6 plus cediranib or bevacizumab) trial were evaluated for baseline levels of VEGF-A, soluble VEGFR-2, and carcinoembryonic antigen (CEA). High baseline VEGF-A (>98 pg/mL) and CEA levels were associated with shorter PFS and OS regardless of treatment. In patients receiving bevacizumab, high expression of sVEGFR-2 was associated with increased PFS and OS [20]. In 2015, a study compared pre-and post-therapeutic VEGF-A IHC expression in 57 mCRC patients treated with bevacizumab and FOLFIRI in order to identify its potential role as predictive biomarkers. Low post-therapeutic VEGF-A scores $(0$ and 1$)$ and decreased peri-therapeutic VEGF-A scores were significant predictive factors of response $(p<0.001)$. On the other hand, high pre-therapeutic VEGF-A scores $(2$ and 3$)$ were not a significant predictive factor $(p=0.772)$. Furthermore, a decrease from score 2 to 1 or 0 between pre-treatment and post-treatment period was a significant predictor factor of response to bevacizumab $(p<0.001)$. Decreased peri-therapeutic VEGF-A scores were also significantly associated with higher 6-month PFS $(p=0.033)$, as well as with longer but not statistically significant OS $(p=0.094)$ [21]. Another group assessed several biomarkers at baseline, 3 and 12 days after a dose of bevacizumab monotherapy, 32 days after initiation of neoadjuvant bevacizumab, fluorouracil, and radiotherapy and 1 week before surgery ( 8 to 9 weeks after completion of preoperative treatment). Notably, patients who experienced greater than 2-fold increases in plasma PIGF after bevacizumab monotherapy had a minimal disease at surgery $(p<0.05)$. Furthermore, bevacizumab alone or in 
combination with chemoradiotherapy increased plasma PIGF, VEGF-A and soluble VEGFR $(p<$ 0.0001). Thus, the researchers concluded that mainly PIGF and VEGF-A might serve as generic pharmacodynamics biomarkers for anti-VEGF therapy as the chemoradiotherapy alone did not seem to change VEGF-A or PlGF [22]. Finally, a meta-analysis that included 11 eligible studies regarding the association of baseline VEGF-A plasma or intratumoral levels with PFS, OS, and objective response, concluded that high levels could predict poor treatment effect of bevacizumab and chemotherapy in mCRC for both PFS $(p=0.0001)$ and OS $(p<0.0001)$ [23].

Beyond VEGF-dependent pathways, several groups have studied other angiogenesis biomarkers. Koeptz S et al. published their results in 2010, investigating whether the changes of 37 plasma cytokines and angiogenic factors can be potential markers of response or resistance to anti-VEGF treatment. Factors were measured with multiplex-bed and ELISA assays at baseline, during treatment and at the time of progression in 43 previously untreated patients, who received bevacizumab and FOLFIRI for mCRC. Significant elevation of pro-angiogenic cytokines, basic fibroblast growth factor (bFGF) $(p=0.046)$, PIGF $(p<0.001)$, and hepatocytes growth factor was observed before radiographic evidence of progressive disease. Based on this observation, investigators concluded that these elevations might represent mechanisms of resistance [24]. Rozoni $\mathrm{M}$ et al. measured with flow cytometry the absolute number of total circulating endothelial cells (tCECs), resting CECs (rCECs), and endothelial progenitor cells (CEPs) at baseline and before the administration of the third and sixth course of treatment in 40 mCRC patients treated with bevacizumab and chemotherapy combination (FOLFIRI, FOLFOX4, XELOX, FOLFOXIRI). They also compared their results with a control group of 50 healthy volunteers. Interestingly, when the absolute number of tCEC $(p=0.01)$ and $\operatorname{rCEC}(p=0.007)$ was $<40$ cells $/ \mathrm{mL}$ at baseline the patients showed longer PFS. Thus, they concluded that CECs could be useful biomarkers for response prediction [25]. Finally, a group from Japan collected blood samples from 99 mCRC patients treated with first-line bevacizumab and mFOLFOX6 or XELOX in order to measure intercellular adhesion molecule 1 (ICAM-1) and interleukin 8 (IL-8) plasma levels. High plasma levels of ICAM-1 were significantly associated with shorter PFS $(p=0.003)$ and high plasma levels of IL-8 with shorter PFS $(p=0.048)$ and OS $(p=0.002)$ [26] (Table 1$)$.

Therefore, VEGF-A levels found to be a significant predictive biomarker in $\mathrm{mCRC}$, too and other pathways have also been identified as promising.

\subsection{Lung Cancer}

During the E4599 phase II/III study, 878 NSCLC patients were randomized to receive carboplatin and paclitaxel with or without bevacizumab. Based on the fact that VEGF-A, bFGF, soluble ICAM-1, and E-selectin are increased in several tumors, researchers performed a prospective biomarker assessment and their correlation to treatment outcomes. Plasma levels were measured before first cycle and after cycle 2. Patients with high baseline VEGF-A levels $(>35.7 \mathrm{pg} / \mathrm{mL})$ had increased probability of a response if bevacizumab was added to their treatment regimen $(33 \% \mathrm{vs.} 7.7 \%, p=0.01)$. In patients with baseline VEGF-A $\leq 35.7 \mathrm{pg} / \mathrm{mL}$, the response was similar, $28.6 \%$ and $29 \%$ for bevacizumab/chemotherapy and chemotherapy only arm, respectively. Low VEGF-A levels were also significantly associated with PFS (6 vs. 4.5 months, $p=0.04$ ). While VEGF-A was predictive of response, low ICAM-1 levels $(\leq 260.5 \mathrm{ng} / \mathrm{mL})$ were prognostic for survival $(p=0.00005)$ and predictive of response to treatment ( $32 \%$ vs. $14 \%, p=0.02)$ and 1-year survival ( $65 \%$ vs. $25 \%)$ [27]. ABIGAIL was another phase II, open-label, randomized, international, and multicenter study, which investigated the correlation between biomarkers (VEGF-A, VEGFR-1, VEGFR-2, bFGF, E-selectin, ICAM-1, and PIGF) in plasma samples at baseline and through treatment with the response to bevacizumab. In total, 303 chemo naive NSCLC patients were randomized to receive bevacizumab $7.5 \mathrm{mg} / \mathrm{kg}$ (154 patients) or $15 \mathrm{mg} / \mathrm{kg}$ (149 patients) in combination with chemotherapy (carboplatin and gemcitabine or carboplatin and paclitaxel). Primary specimen tumor samples were also analyzed for VEGF-A, VEGFR-1, VEGFR-2, bFGF, E-selectin, PIGF, neuropilin (NRP), ICAM-1 and CD31. Baseline and dynamic changes in plasma levels of VEGFR-1, VEGFR-2, bFGF, E-selectin, ICAM-1, and PIGF did not correlate with response to 
bevacizumab. However, low baseline plasma VEGF-A levels were correlated with longer PFS (7.4 vs. 6.1 months, $p=0.002)$ and longer median OS (19.8 vs. 11.1 months, $p=0.004)$. As a result, the authors reported that VEGF-A might be promising biomarker [28].

A phase II trial in patients with extensive-stage small-cell lung cancer assessed efficacy and safety of bevacizumab, cisplatin, and etoposide combination in 63 patients. Correlative studies were performed in order to explore any potential relationship between treatment outcome and plasma levels of VEGF-A, soluble vascular cell adhesion molecules (VCAM), ICAM-1, E-selectin, and bFGF. Blood samples collected before cycle 1 and after completion of cycle 2. High baseline VCAM levels predicted survival as they were associated with higher risk of progression $(p=0.05)$ and death $(p=0.01)$ compared to low levels. High bFGF and ICAM-1 levels also showed a trend toward a higher risk of death ( $p=0.06$ both). The response was not associated significantly with baseline VEGF-A $(p=0.43)$ or any other biomarker [29].

In agreement with other tumor types, VEGF-A, and ICAM-1 levels found to be promising predictive biomarkers.

\subsection{Ovarian Cancer}

In the ovarian cancer setting, phase III GOG-0218 trial, compared carboplatin and paclitaxel with placebo, bevacizumab followed by placebo, or bevacizumab followed by bevacizumab. Baseline plasma samples were available from 751 participants and were analyzed via multiplex ELISA technology for seven potential biomarkers (IL-6, Ang-2, osteopontin (OPN), stromal cell-derived factor-1 (SDF-1), VEGF-D, IL6 receptor (IL-6 R), and GP130). In patients treated with bevacizumab, high IL-6 levels found to be predictive of PFS ( $p=0.007)$ and OS ( $p=0.003)$ [30].

Levels of IL-6 were found to be significantly associated with clinical outcomes in patients treated with bevacizumab for ovarian cancer. Other promising biomarkers such as VEGF-A, ICAM-1, and IL-8 levels were not assessed in this setting.

\subsection{Renal-Cell Cancer (RCC)}

Baseline plasma samples were collected from 424 consenting patients with renal-cell cancer, participating at CALGB 90206 phase III trial that was comparing bevacizumab and interferon-A versus interferon alone. ELISA was used to measure 32 candidate factors related to tumor growth, angiogenesis, and inflammation. IL-6 and hepatocyte growth factor (HGF) levels were positively correlated with OS in patients treated with bevacizumab. The authors reported that these factors might identify patients who will benefit most from bevacizumab and could guide clinical decisions and patients selection in future trials [31].

In line with results from ovarian cancer, IL-6 seems to be a promising candidate biomarker.

\subsection{Glioblastoma}

Sathornsumetee $S$ et al. used tumor specimens collected at diagnosis from 45 patients (27 glioblastoma multiforme and 18 anaplastic astrocytoma), who were treated with bevacizumab and irinotecan. They retrospectively evaluated tumor vascularity and expression of components of VEGF pathway and hypoxic response as predictive markers for radiographic response and survival in tumor expression of VEGF-A, VEGFR-2, CD31 hypoxia-inducible cardonic anhydrase 9 (CA9), and hypoxia-inducible factor-2a (HIF-2a) were semi quantitatively assessed by immunohistochemistry (IHC). High VEGF-A expression (mean positive area $>5000$ pixels/400 field) was associated with increased likelihood of radiographic response $(p=0.024)$. Moreover, high CA9 expression (mean positive area $>10,000$ pixels/high-powered field) was associated with poor 1-year survival after initiation of bevacizumab treatment (37 vs. 74 weeks, $p=0.02$ ). Similarly, a trend was observed between HIF-2a expression and poor 1-year survival $(p=0.07)$. No significant differences in radiographic response or survival were reported for VEGFR-2 and CD31 ( $p>0.1)$ [32]. 
To sum up, there are enough data from various types of tumors to support the rationale for the use of specific biomarkers as prognostic or predictive factors for the response. The most promising of them seems to be plasma VEGF-A and ICAM-1 levels as it has been associated in many studies with the response, OS, and PFS. It is also feasible to measure it, in contrast to intra-tumoral factors, and there are commercially available and validated ELISA kits for them.

\section{Genetic Biomarkers-Pharmacogenomics (PG)}

Several research groups have investigated the role of specific genotypes and single nucleotide polymorphisms (SNPs) in outcomes of bevacizumab treatment, as there is a substantial germline genetic variability within angiogenesis pathway genes, which causes interindividual differences in angiogenic capacity and resistance to anti-angiogenesis treatment. Some studies have also investigated the effect of genetic polymorphisms in bevacizumab-induced toxicity Pharmacogenomic biomarkers have been assessed as potential predictive biomarkers in $\mathrm{mBC}, \mathrm{mCRC}$, lung cancer, ovarian, and glioblastoma.

\subsection{Metastatic Breast Cancer (mBC)}

The association of VEGF-A and VEGFR-2 genotypes with clinical outcomes was evaluated in phase III E2100 study comparing paclitaxel with bevacizumab and paclitaxel as initial chemotherapy for $\mathrm{mBC}$. DNA was extracted from 363 tumor block samples. In the paclitaxel arm, there was no significant association between any genotype and response rate (RR), PFS, or OS. OS was 25.2 months for paclitaxel arm and 26.7 months for the combination arm not subdivided by genotype $(p=0.16)$. However, the median OS was significantly longer for subgroups VEGF- $A$ rs699947 $(p=0.035)$ and VEGF-A rs1570360 A/A $(p=0.047)$ in the combination arm, 37 and 46.5 months, respectively. Development of grade 3 or 4 hypertension was correlated with two other polymorphisms VEGF-A rs $2010963 \mathrm{C} / \mathrm{C}(0 \%, p=0.005)$ and VEGF-A rs3025039 T/T ( $8 \%, p=0.022)$. Finally, a patient who developed grade 3 or 4 hypertension had a superior median OS of 36.7 months compared to 25.3 months in patients who did not develop hypertension $(p=0.012)$ [33]. Another prospective study, which tested the impact of VEGF-A gene polymorphisms on the pharmacodynamics of first-line bevacizumab-containing therapy in 137 breast cancer patients, pointed out the potential role of $V E G F-A$ polymorphisms. $V E G F-A$ rs2010963 C $>\mathrm{T}$ polymorphism revealed that patients bearing the $\mathrm{T}$ allele exhibited a longer time-to-progression (TTP) compared to homozygous for the $\mathrm{C}$ allele (11.5 vs. 9.7 months, $p=0.022)$. None of the other studied polymorphisms influence TTP, OS or clinical response. However, VEGF-A rs2010963 G>C was significantly associated with toxicity $(p=0.01)$ and patients with $C$ allele were more prone to develop hypertension and thromboembolism [34] (Table 2).

Investigators of the randomized phase III GeparQuinto study tested whether SNPs in VEGF pathway genes correlate with complete pathological response after neoadjuvant treatment in 729 patients treated with bevacizumab and chemotherapy and in 725 treated only with chemotherapy for HER-2 negative breast cancer. Four SNPs of VEGF-A rs833058 ( $p=0.003)$, rs699947 $(p=0.032)$, $\operatorname{rs3025039}(p=0.040), \operatorname{rs} 3025030(p=0.041)$, and one SNP of VEGFR-1 (FLT1) rs79995976 ( $p=0.049)$ were associated with better response, but they did not remain significant after correction for multiple testing. Investigators suggested that further research is warranted to clarify the predictive value of these markers [35] (Table 2).

VEGFR-2 rs 11133360 and IL-8 rs4073 genotypes proved to be able to identify patients who will benefit more from bevacizumab treatment with a better outcome. In total, $113 \mathrm{mBC}$ patients treated with first-line paclitaxel and bevacizumab were enrolled. The combination between specific VEGFR-2 rs11133360 and IL-8 rs4073 genotypes showed a statistically significant difference in median PFS for favorable and unfavorable genetic profiles (14.1 vs. 10.2 months, $p<0.0001$ ) [36] (Table 2).

Genes not associated with VEGF pathway have also been investigated in $\mathrm{mBC}$. Endothelial nitric oxide synthase (eNOS) rs1799983 polymorphisms and IL-8 rs4073 T/A were also assessed by another group in $31 \mathrm{mBC}$ patients treated with bevacizumab and chemotherapy. None of the analyzed polymorphisms were associated with RR. However, IL-8 rs4073 A/A genotype showed a significantly 
lower PFS for the following combinations: T/T vs. A/A (13 vs. 8 months, $p=0.008$ ), T/T vs. T/A vs. $\mathrm{A} / \mathrm{A}(13$ vs. 11 vs. 8 months, $p=0.02), \mathrm{T} / \mathrm{T}$ vs. T/A+A/A (13 vs. 11 months, $p=0.01$ ), T/T+T/A vs. A/A (12 vs. 8 months, $p=0.01$ ) and a lower OS, when compared with TT+TA genotype ( 26 vs. 51 months, $p=0.04)$. eNOS rs1799983 T/T genotype predisposed to statistically significant lower PFS compared to $\mathrm{G} / \mathrm{G}$ genotype (11.5 vs. 26.5 months, $p=0.04$ ), but no differences in OS. These results suggest that $I L-8$ rs4073 T/A and eNOS rs1799983 G/T polymorphisms could be predictive of treatment outcomes [37] (Table 2).

Studies in $\mathrm{mBC}$ have identified promising genetic biomarkers, mainly polymorphisms of VEGF- $A$ genes that are correlated with both efficacy and toxicity (Table 2).

\subsection{Metastatic Colorectal Cancer ( $m C R C)$}

A recently published study investigated the effect of SNPs in VEGF-dependent and non-VEGF-dependent angiogenesis pathways on clinical outcomes in $46 \mathrm{mCRC}$ patients treated with first-line bevacizumab-based treatment. Interestingly, two SNPs in VEGF- $A$ and ICAM-1 genes were identified as predictors of clinical outcomes. VEGF-A rs699947 A/A allele was significantly associated with increased PFS (32.6 vs. 8.1 months, $p=0.006)$ and OS (59.4 vs. 16.9 months, $p=0.043$ ) compared to C/C allele. Besides, ICAM-1 rs1799969 G/A allele was associated with prolonged OS (48.7 vs. 29.1 months, $p=0.036$ ). Therefore, the authors concluded that VEGF-A and ICAM-1 genes could be used to identify patients who will achieve long-term responses and benefit from bevacizumab-based therapies [38]. Mutations in VEGF-A rs699947 and ICAM-1 rs1799969 have also been associated with better binding of bevacizumab to VEGF-A and lower bevacizumab clearance in patients with mCRC. These association may also partly explain the associations between these polymorphisms and favorable clinical outcomes [39]. Loupakis et al. conducted a retrospective exploratory analysis of VEGF-A polymorphisms. They used the genomic DNA of $111 \mathrm{mCRC}$ patients treated with bevacizumab and FOLFIRI and as control 107 patients treated only with FOLFIRI. In the control group, no significant association was observed. However, in the bevacizumab group VEGF-A rs833061, C/C, C/T, and T/T polymorphisms were significantly associated with PFS (12.8 vs. 10.5 vs. 7.5 months, $p=0.0046)$ and OS (27.3 vs. 20.5 vs. 18.6 months, $p=0.0020)$. Based on the absence of differences in control, group investigators reported that the relation of VEGF- $A$ rs833061 T/T genotype with shorter PFS was caused by the effect of bevacizumab $(p=0.011)$ [40]. Loupakis et al. also conducted a prospective study in a large clinically homogenous cohort of $\mathrm{mCRC}$ patients treated with first-line bevacizumab and FOLFIRI in order to evaluate candidate SNPs of VEGF/VEGFR pathway as potential predictors of response. They enrolled 424 patients and found a significant association between VEGFR-2 rs 12505758 $\mathrm{C} / \mathrm{T}$ variants and PFS $(p=0.045)$. They also developed a multivariate model including histology, ECOG performance status, baseline LDH, number of metastatic sites, and primary tumor sites as covariates variants. It showed that patients with at least one C-allele exhibited lower PFS of 9.5 months compared with 10.9 months of homozygous for T/T ( $p=0.012)$ [41] (Table 2).

Apart from VEGF-A polymorphisms Ulivi et al. also investigated polymorphisms of $e N O S$ and their relation to response to bevacizumab in $237 \mathrm{mCRC}$ patients ( 114 of them received chemotherapy and bevacizumab). Their panel included five SNPs for VEGF-A (rs1570360, rs699947, rs2010963, and rs833061), two for $e N O S$, as well as one variable number tandem repeat in intron 4 for $e N O S$. In the group of patients, who received bevacizumab VEGF- $A$ rs2010963 T/T genotype was associated with a shorter median PFS compared to other genotypes (7.8 vs. 10.4 months, $p=0.036$ ), while no significant difference was detected in the other groups. Similarly, eNOS rs1799983 G/T predisposed to shorter PFS (8.9 vs. 11.9 months, $p=0.013$ ), whereas eNOS VNTR466 predisposed to longer PFS (10.9 vs. 9.1, $p=0.034)$. Interesting associations were also detected between OS and some polymorphism when bevacizumab was administrated. Patients had significantly shorter OS if VEGF-A rs2010963 $\mathrm{T} / \mathrm{T}$ (8.6 vs. 22.7, $p=0.007)$ or $e$ NOS rs1799983 G/T (20.1 vs. $26.1, p=0.014)$ were present. On the other hand, eNOS VNTR 466 was also relevant to longer OS ( 24.8 vs. 20.6 months, $p=0.015$ ). Thus, researchers concluded that a haplotype combination of eNOS polymorphisms is capable of 
identifying who may or will probably benefit from bevacizumab-based chemotherapy [42]. Gerger et al. published their results of studying a comprehensive panel of germline polymorphisms of angiogenesis genes and their ability to predict clinical outcome and tumor response. Their study population was 132 mCRC patients treated with first-line bevacizumab in combination with FOLFOX or XELOX. Increased $O S$ was observed in patients carrying at least one $G$ allele of epidermal growth factor gene (EGF) rs444903A $>G$ (32.4 vs. 12.1 months, $p=0.012)$ and of insulin-like growth factor 1 gene (IGF-1) rs6220A $>G$ (32.4 vs. 21.9). These results remained significant and in multivariate COX regression analysis. Another interesting finding was the association of the minor allele of HIF-1a rs11549465C $>\mathrm{T}$ with increased PFS compared to homozygous C/C (11.7 vs. 10.2, $p=0.038)$. Finally, in response rate significant differences were found between patients homozygous for the wild-type alleles of CXCR1 rs2234671G $>C$ compared to those carrying one or two minor alleles $(71 \%$ vs. $37 \%$ vs. $17 \%, p<0.001)$ and of VEGFR-2 $\mathrm{rs} 2305948 \mathrm{C}>\mathrm{T}(57 \%$ vs. $29 \%$ vs. $13 \%, p=0.024)$. In contrast, lower response rate was presented in patients harboring wild-type of $C X C R 2$ rs2230054T $>C$ compared to heterozygous and homozygous for one minor allele ( $38 \%$ vs. $56 \%$ vs. $79 \%, p=0.008)$ and of VEGFR rs $2227983 \mathrm{G}>\mathrm{A}$ ( $43 \%$ vs. $55 \%$ vs. $82 \%, p=0.024$ ) [43]. In $40 \mathrm{mCRC}$ patients treated with bevacizumab and FOLFIRI germline VEGF- $A$ genes polymorphisms were associated with treatment outcomes. PFS was shorter in carriers of VEGF- $A$ rs $833061 \mathrm{G} / \mathrm{G}$ compared to G/A +A/A ( 8.9 vs. 15.4 months, $p=0.007)$ and VEGF- $A$ rs $1570360 \mathrm{G} / \mathrm{G}$ compared to $\mathrm{G} / \mathrm{A}+\mathrm{A} / \mathrm{A}$ (9.8 vs. 16 months, $p=0.03$ ). They also performed multivariate analysis, including biochemical variables known to influence prognosis, which showed that VEGF- $A$ rs1570360 G/G retained an independent predictive value for PFS compared to G/A + A/A ( $p=0.02)$. Concerning response rate, VEGF- $A$ rs $2010963 \mathrm{G} / \mathrm{G}$ was significantly associated with response compared to $\mathrm{G} / \mathrm{C}+\mathrm{C} / \mathrm{C}(64 \%$ vs. $14 \%, p=0.03)$ [44]. Another promising predictive marker is CD133. In a study of $91 \mathrm{mCRC}$ or recurrent CRC patients treated with first-line bevacizumab and FOLFOX or XELOX, those with high intratumoral gene expression levels of CD133 (>7.76) had significantly better tumor response compared to those with gene expression $\leq 7.76(86 \%$ vs. $38 \%, p=0.003)$. Moreover, these patients presented higher VEGF-A or VEGFR expression levels (VEGF-A, VEGFR-2, VEGFR-3, $p<0.09$, and VEGFR-1, $p<0.01$ ). In combination analysis after adjustment for sex and number of metastatic sites, multivariate analysis showed that CD133 polymorphisms of rs2286455 and rs3130 are independent prognostic factors for PFS $(p=0.002)$ [45]. The same conclusion was drawn by another study in an mCRC setting, where the authors stated that their results should be validated prospectively, in larger cohorts. In total, 173 patients treated with bevacizumab in combination with FOLFIRI or XELIRI participated and their blood samples genotyped for SNPs VEGF-A (rs1570360, rs699947, and rs2010963). VEGF-A rs $1570360 \mathrm{G} / \mathrm{G}$ was more frequent in non-responders compared with responders $(65.5 \% \mathrm{vs}$. $39.8 \%, p=0.032)$. Furthermore, it was associated with an inferior median OS compared with GA $(p=0.016)$ or with GA and AA combination $(p=0.017)$. In multivariate analysis, the VEGF-A rs 1570360 $\mathrm{G} / \mathrm{G}$ genotype remained a significant adverse factor for OS [46]. An Asian group conducted a study to evaluate 12 SNPs of angiogenic genes in $125 \mathrm{mCRC}$ patients, who received first-line bevacizumab and chemotherapy. They reported that VEGF-A rs833061T/T was associated with superior RR compared to its alternative genotypes ( 75.9 vs. $50.8 \%, p=0.008)$. Median PFS ( 8.7 vs. 6.6 months, $p=0.001$ ) and OS (26.4 vs. 16.1 months, $p=0.038$ ) were superior in patients with the fms-related tyrosine kinase 1 (FLT1) rs9513070A/A genotype. Haplotype analysis associated the FLT1 rs9513070/rs9554320/rs9582036 G/C/A haplotype with inferior PFS $(p=0.004)$ and OS $(p=0.041)$ [47]. Finally, a meta-analysis including 60 studies and analyzing five VEGF-A polymorphisms (rs3025039, rs833058, rs1570360, rs699947, and rs2010963), identified a significant prognostic relationship of VEGF- $A$ rs833058 variants, as the carriers of them showed a highly statistically significant improvement in OS $(p=0.004)$ [48] (Table 2).

Independently of angiogenesis genes, Matsusaka et al. investigated if SNPs in genes involved in IL-6/STAT3 signaling, IL-6 (rs2069837 and rs1800795) and STAT3 (rs744166 and rs4796793) can predict PFS, OS, and response to first-line FOLFIRI plus bevacizumab in mCRC setting. Researchers used data from two randomized phase III trials: TRIBE (223 patients), training cohort, and FIRE-3 (288 patients, validation cohort, and 264 control cohort). IL-6 rs2069837G was associated with longer PFS 
than the A/A genotype both in TRIBE (9.4 vs. 11.1 months, $p=0.004)$ and FIRE-3 (8.8 vs. 10.9 months, $p=0.015)$ trials. These associations were confirmed in multivariable analyses and were not seen in the control cohort [49]. A study conducted in 58 patients treated with bevacizumab, irinotecan, and fluoropyrimidines for mCRC evaluated the association between CD133 rs3130 and rs2286455 polymorphisms and treatment outcomes. Significant association was observed only for rs $3130 \mathrm{C} / \mathrm{C}$ genotype, which was associated with reduced toxicity of treatments $(p=0.0017)$ and with lower OS $(p=0.002)$ [50]. Matsusaka et al. again studied an important mechanism of resistance to angiogenesis inhibition: the ability of epithelial-mesenchymal transition (EMT) pathway genetic variants to predict the efficacy of antiangiogenic therapy. They analyzed associations between functional SNPs in EMT-related genes and outcomes of first-line bevacizumab-based chemotherapy in $143 \mathrm{mCRC}$ patients; they also used a control of 77 patients treated with cetuximab-based chemotherapy. Studied SNPs included TWIST1 (rs2285682 and rs2285681), ZEB1 (rs10826943 and rs2839658), SNAIL (rs1543442 and rs4647958), and E-cadherin (rs16260). Carriers of a TWIST1 rs2285682 G allele had a significantly longer median PFS compared with those with the T/T genotype (18.1 vs. 13.3 months, $p=0.003$ ) and OS (44.1 vs. 29.2 months, $p=0.001$ ) in the bevacizumab cohort. These associations remained significant also in multivariate analysis. Moreover, improved PFS and OS were associated in multivariate analysis revealed with the combination of female sex and TWIST1 rs2285682 G (PFS, $p=0.007$; OS, $p=0.001$ ) and rs2285681 G genotypes (PFS, $p<0.001$; OS, $p<0.001$ ). No significant associations were found in the cetuximab cohort, suggesting that TWIST1 polymorphisms may serve as clinically useful biomarkers for antiangiogenic therapy [51] (Table 2).

Similarly, to mBC studies, polymorphisms of VEGF-A, eNOS, and VEGF-R genes were associated significantly with outcomes in mCRC patients treated with bevacizumab (Table 2).

\subsection{Lung Cancer}

Apart from circulating biomarkers ABIGAIL trial also performed exploratory analyses of 12 SNPs across three genes are of VEGF-A, VEGFR-1, and VEGFR-2. Genetic variants at VEGF-A and VEGFR-1 were associated with treatment outcome. Especially, VEGF rs699947 C $>$ A was associated with $>50 \%$ higher response rate, $\mathrm{rs} 2010963 \mathrm{C}>\mathrm{T}$ was associated with higher incidence of hypertension and VEGFR-1 rs9554316 G/T was associated with $>30 \%$ higher risk of progression and $>40 \%$ higher risk of death [52] (Table 2).

In line with $\mathrm{mBC}$ and $\mathrm{mCRC}$ studies VEGF- $A$ and $V E G F-R$ genes were identified as potential biomarkers (Table 2).

\subsection{Ovarian Cancer}

Schultheis AM et al. used genomic DNA from blood samples of 53 patients with recurrent or metastatic epithelial ovarian cancer and evaluated the association between angiogenesis gene polymorphisms and outcome of bevacizumab and low-dose cyclophosphamide treatment. They found that patients homozygous for CXCR2 rs2230054 T/T polymorphism had significantly lower median PFS compared to patients carrying at least one $C$ allele ( 3.7 vs. 7.4 months, $p=0.026$ ). Patients heterozygous for VEGF-A rs3025039 C/T had longer median PFS of 11.8 months compared to 5.5 months for homozygous C/C and only 3.2 months for homozygous T/T. When they combined genetic data, they found that patients carrying both adremmedullin $3^{\prime}$ and alleles $<14 C A$ repeats had lower median PFS compared to those with at least one allele $\geq 14 \mathrm{CA}$ ( $3.4 \mathrm{vs}$. 6.4 months) or both alleles $\geq 14 \mathrm{CA}$ ( $3.4 \mathrm{vs}$. 7.2 months) $(p=0.008)$. Additionally, patients with A/A or A/T genotype at the -251 locus of the IL- 8 gene had lower response rate than those who were $\mathrm{T} / \mathrm{T}$ homozygous $(p=0.006)$. These data suggest that genes independent of VEGF play an important role in the mechanism of resistance to anti-VEGF therapy [53] (Table 2).

Similarly, to $\mathrm{mBC}$ and mCRC studies VEGF- $A$ and $I L-8$ genes were identified as potential biomarkers (Table 2). 


\subsection{Renal-Cell Cancer (RCC)}

One large study investigated DNA from patients from two phase III randomized studies (AViTA and AVOREN). Correlation of 138 SNPs in the VEGF pathway with PFS and OS was assessed. VEGFR-1 rs9582036 AA, was significantly associated with longer OS $(p=0.00014)$ and PFS $(p=0.00081)$ in the bevacizumab group of AViTA after correction for multiplicity, but no effects in placebo patients $(p=0.041)$ were seen or recorded, indicating that the VEGFR-1 locus containing this SNP serves as a predictive marker for bevacizumab treatment outcome. Interestingly, this locus correlated significantly with PFS ( $p=0.033$ ) also in the bevacizumab group in AVOREN in patients with metastatic pancreatic adenocarcinoma [54] (Table 2).

\subsection{Glioblastoma}

The correlation between 14 SNPs of VEGF-A, VEGFR-2, and HIF-1 $a$ with treatment efficacy and toxicity was examined in 54 patients receiving bevacizumab and sorafenib for recurrent glioblastoma. Mutations of VEGF- $A$ and VEGFR-2 promoters were significantly associated with 6-month PFS success. It was increased for mutant VEGF-A rs699947 $(p=0.011)$, rs833061 $(p=0.013)$, and heterozygous VEGFR-2 rs2071559 ( $p=0.025)$, but it was decreased for mutant VEGF- $A$ rs1005230 $(p=0.011)$ and $\operatorname{rs} 1570360(p=0.004)$. Notably, increased incidence of grade $\geq 3$ hypertension was observed in heterozygous patients for VEGF-A promoter rs1005230 ( $p=0.006)$, rs699947 $(p=0.006)$, and rs833061 $(p=0.010)$. Researchers concluded that their data represent the first evidence that VEGF-A and VEGFR-2 genetic polymorphisms could predict outcome in glioblastoma patients treated with bevacizumab [55]. These findings are in line with the results of studies in other indications (Table 2).

Most of the studies revealed a significant correlation between specific polymorphisms and genotypes with the response, OS, and PFS. It is also important that large, prospective studies and meta-analyses have found a positive relation between genetic factors and outcome. In addition, the association has been confirmed in many cases by multivariate analyses. The most promising polymorphisms are those of VEGF-A, ICAM-1, VEGF-R, eNOS, and IL-8 (Table 2). Further randomized trials and genome-wide association studies in the future could offer solid and validated results that will make antiangiogenic treatment more precise. 
Table 1. Available studies on proteinic biomarkers associated with response to bevacizumab.

\begin{tabular}{|c|c|c|c|c|c|}
\hline Reference & Tumor Type & $\begin{array}{l}\text { Number of } \\
\text { Patients }\end{array}$ & Treatment & Biomarkers & Findings \\
\hline $\begin{array}{l}\text { Alvarez Secord A } \\
\text { et al. [30] }\end{array}$ & Ovarian cancer & 751 & $\begin{array}{l}\text { Chemotherapy (carboplatin and } \\
\text { paclitaxel) plus placebo vs. } \\
\text { chemotherapy (carboplatin and } \\
\text { paclitaxel) plus bevacizumab }\end{array}$ & $\begin{array}{l}\text { Plasma levels of IL-6, Ang-2, OPN, SDF-1, } \\
\text { VEGF-D, IL-6 R, and GP130 at baseline }\end{array}$ & $\begin{array}{l}\text { High IL- } 6(>22.1 \mathrm{pg} / \mathrm{mL}) \text { levels were } \\
\text { associated with significantly improved PFS } \\
\text { and OS in patients treated with bevacizumab }\end{array}$ \\
\hline $\begin{array}{l}\text { Burstein HJ, } \\
\text { et al. [17] }\end{array}$ & $\mathrm{mBC}$ & 56 & Vinorelbine plus bevacizumab & Plasma VEGF-A levels at baseline & $\begin{array}{c}\text { Baseline levels }>32.6 \mathrm{pg} / \mathrm{mL} \text { associated with } \\
\text { shorter time to progression and no tumor } \\
\text { control }\end{array}$ \\
\hline $\begin{array}{l}\text { Dowlati A } \\
\text { et al. [27] }\end{array}$ & NSCLC & 878 & $\begin{array}{l}\text { Carboplatin and paclitaxel vs. } \\
\text { carboplatin and paclitaxel plus } \\
\text { bevacizumab }\end{array}$ & $\begin{array}{l}\text { Plasma levels of VEGF-A, bFGF, soluble } \\
\text { ICAM-1, and E-selectin at baseline and after } \\
\text { cycle } 2 \text {. }\end{array}$ & $\begin{array}{l}\text { High baseline VEGF-A plasma levels (>35.7 } \\
\mathrm{pg} / \mathrm{mL} \text { ) were associated with better response } \\
\text { in patients treated with bevacizumab. } \\
\text { Whereas, low ICAM-1 levels }(\leq 260.5 \mathrm{ng} / \mathrm{mL} \text { ) } \\
\text { were prognostic for survival and predictive } \\
\text { of response regardless of the administration } \\
\text { of bevacizumab }\end{array}$ \\
\hline Horn L et al. [29] & $\begin{array}{l}\text { Small-cell lung } \\
\text { cancer }\end{array}$ & 63 & $\begin{array}{l}\text { Cisplatin and etoposide plus } \\
\text { bevacizumab }\end{array}$ & $\begin{array}{l}\text { Plasma levels of VEGF-A, soluble VCAM, } \\
\text { ICAM-1, E-selectin and bFGF at baseline and } \\
\text { after completion of cycle } 2\end{array}$ & $\begin{array}{l}\text { High baseline VCAM plasma levels were } \\
\text { associated with higher risk of progression } \\
\text { and death }\end{array}$ \\
\hline Jubb AM, et al. [18] & $\mathrm{mBC}$ & 462 & $\begin{array}{c}\text { Capecatibine vs. capecatibine plus } \\
\text { bevacizumab }\end{array}$ & $\begin{array}{l}\text { Expression of VEGF-A, VEGF-B, THBS-2, } \\
\text { Flt4, VEGF-C, PDGF-C, neuropilin-1, } \\
\text { delta-like ligand D114, Bv8, p53, and } \\
\text { thymidine phosphorylase in tumor tissue }\end{array}$ & $\begin{array}{l}\text { VEGF-A expression was predictive of PFS in } \\
\text { patients treated with bevacizumab }\end{array}$ \\
\hline Jubb AM, et al. [19] & $\mathrm{mCRC}$ & 813 & IFL vs. IFL plus bevacizumab & $\begin{array}{l}\text { Expression of the stromal and epithelial } \\
\text { VEGF-A, THBS-2 score, MVD in tumor tissue }\end{array}$ & $\begin{array}{l}\text { None of the tested biomarkers were } \\
\text { predictive of survival }\end{array}$ \\
\hline $\begin{array}{l}\text { Jürgensmeier, J, } \\
\text { et al. [20] }\end{array}$ & $\mathrm{mCRC}$ & 1254 & $\begin{array}{l}\text { mFOLFOX6 plus cediranib vs. } \\
\text { mFOLFOX6 plus bevacizumab }\end{array}$ & $\begin{array}{c}\text { Plasma VEGF-A, soluble VEGFR-2 and CEA } \\
\text { levels at baseline }\end{array}$ & $\begin{array}{l}\text { High baseline VEGF-A }(>98 \mathrm{pg} / \mathrm{mL}) \text { and } \\
\text { CEA levels were associated with shorter PFS } \\
\text { and OS regardless of treatment }\end{array}$ \\
\hline Koeptz S et al. [24] & $\mathrm{mCRC}$ & 43 & FOLFIRI plus bevacizumab & $\begin{array}{l}37 \text { plasma cytokines and angiogenic factors } \\
\text { (CAFs) }\end{array}$ & $\begin{array}{l}\text { Significant elevation of pro-angiogenic } \\
\text { cytokines (bFGF, PIGF, and hepatocytes } \\
\text { growth factor) was associated with } \\
\text { resistance to treatment }\end{array}$ \\
\hline Mok T et al. [28] & NSCLC & 303 & $\begin{array}{l}\text { Chemotherapy (carboplatin and } \\
\text { paclitaxel, carboplatin and } \\
\text { gemcitabine) plus bevacizumab }\end{array}$ & $\begin{array}{l}\text { Plasma levels of VEGF-A, VEGFR-1, } \\
\text { VEGFR-2, bFGF, E-selectin, ICAM-1, PIGF at } \\
\text { baseline and through treatment }\end{array}$ & $\begin{array}{l}\text { Low baseline VEGF-A plasma levels were } \\
\text { correlated with prolonged PFS and OS }\end{array}$ \\
\hline Nixon A et al. [31] & Renal-cell cancer & 424 & $\begin{array}{l}\text { interferon-A plus bevacizumab vs. } \\
\text { interferon-A }\end{array}$ & $\begin{array}{l}\text { Baseline plasma levels of } 32 \text { factors related to } \\
\text { tumor growth, angiogenesis, and } \\
\text { inflammation }\end{array}$ & $\begin{array}{l}\text { IL- } 6 \text { and HGF plasma levels at baseline were } \\
\text { positively correlated with OS in patients } \\
\text { treated with bevacizumab }\end{array}$ \\
\hline
\end{tabular}


Table 1. Cont.

\begin{tabular}{|c|c|c|c|c|c|}
\hline Reference & Tumor Type & $\begin{array}{l}\text { Number of } \\
\text { Patients }\end{array}$ & Treatment & Biomarkers & Findings \\
\hline $\begin{array}{l}\text { Rozoni M } \\
\text { et al. [25] }\end{array}$ & $\mathrm{mCRC}$ & 40 & $\begin{array}{c}\text { Chemotherapy (FOLFIRI, FOLFOX4, } \\
\text { XELOX, FOLFOXIRI) plus } \\
\text { bevacizumab }\end{array}$ & $\begin{array}{l}\text { Absolute number of total circulating } \\
\text { endothelial cells ( } \mathrm{tCECs}) \text {, resting CECs } \\
\text { (rCECs) and endothelial progenitor cells } \\
\text { (CEPs) at baseline and before the } \\
\text { administration of the third and sixth course } \\
\text { of treatment and compared their results with } \\
\text { a control group of } 50 \text { healthy volunteers }\end{array}$ & $\begin{array}{c}\text { The absolute number of } \mathrm{tCEC} \text { and } \mathrm{rCEC}<40 \\
\text { cells/mL at baseline was associated with } \\
\text { longer PFS }\end{array}$ \\
\hline $\begin{array}{l}\text { Sathornsumetee S } \\
\text { et al. [32] }\end{array}$ & Malignant gliomas & 45 & Irinotecan plus bevacizumab & $\begin{array}{c}\text { Tumor expression of VEGF-A, VEGFR-2, } \\
\text { CD31, CA9, and HIF-2a }\end{array}$ & $\begin{array}{l}\text { High VEGF-A expression ( }>5000 \text { pixels/x400 } \\
\text { field) was associated with increased } \\
\text { likelihood of radiographic response and high } \\
\text { CA9 expression }(>10000 \\
\text { pixels/high-powered field) was associated } \\
\text { with poor 1-year survival }\end{array}$ \\
\hline Tsai HL, et al. [21] & $\mathrm{mCRC}$ & 57 & FOLFIRI plus bevacizumab & $\begin{array}{l}\text { Pre-and post-therapeutic VEGF-A IHC } \\
\text { expression }\end{array}$ & $\begin{array}{l}\text { Low post-therapeutic VEGF-A scores ( } 0 \text { and } \\
1 \text { ) and decreased peri-therapeutic VEGF-A } \\
\text { scores were significant predictive factors of } \\
\text { response. High pre-therapeutic VEGF-A } \\
\text { scores ( } 2 \text { and } 3 \text { ) were not a significant } \\
\text { predictive factor, but a decrease from score } 2 \\
\text { to } 1 \text { or } 0 \text { between pre-treatment and } \\
\text { post-treatment period was a significant } \\
\text { predictor factor of response to bevacizumab. } \\
\text { Decreased peri-therapeutic VEGF-A scores } \\
\text { were also significantly associated with } \\
\text { higher 6-month PFS }\end{array}$ \\
\hline $\begin{array}{l}\text { Willett CG, } \\
\text { et al. [22] }\end{array}$ & Rectal cancer & 32 & $\begin{array}{l}\text { Neoadjuvant bevacizumab } \\
\text { monotherapy, bevacizumab plus } \\
\text { fluorouracil and radiotherapy }\end{array}$ & $\begin{array}{l}\text { PIGF, IL-6, CECs, sVEGF-A1, and VEGFR at } \\
\text { baseline, } 3 \text { and } 12 \text { days after a dose of } \\
\text { bevacizumab monotherapy, } 32 \text { days after } \\
\text { initiation of neoadjuvant bevacizumab, } \\
\text { fluorouracil and radiotherapy and } 1 \text { week } \\
\text { before surgery }\end{array}$ & $\begin{array}{l}\text { Greater than 2-fold increases in plasma PIGF } \\
\text { after bevacizumab monotherapy was } \\
\text { associated with minimal disease at surgery. } \\
\text { Pretreatment sVEGFR1 inversely correlated } \\
\text { with the extent of regression, and early } \\
\text { kinetics of PIGF after bevacizumab, and } \\
\text { VEGF-A and IL-6 levels during combined } \\
\text { treatment may predict better outcomes }\end{array}$ \\
\hline $\begin{array}{l}\text { Yamamoto Y } \\
\text { et al. [26] }\end{array}$ & $\mathrm{mCRC}$ & 99 & $\begin{array}{c}\text { Chemotherapy (mFOLFOX6, XELOX) } \\
\text { plus bevacizumab }\end{array}$ & Baseline plasma levels of ICAM-1 and IL-8 & $\begin{array}{l}\text { Plasma levels of ICAM- } 1 \text { and IL- } 8 \text { at baseline } \\
\text { were significantly associated with shorter } \\
\text { PFS and shorter PFS and OS respectively }\end{array}$ \\
\hline
\end{tabular}


Table 2. Available studies on gene polymorphisms associated with response to bevacizumab.

\begin{tabular}{|c|c|c|c|c|c|}
\hline Reference & $\begin{array}{l}\text { Tumor } \\
\text { Type }\end{array}$ & $\begin{array}{l}\text { Number of } \\
\text { Patients }\end{array}$ & Treatment & Biomarkers & Findings \\
\hline $\begin{array}{l}\text { Allegrini G } \\
\text { et al. [36] }\end{array}$ & $\mathrm{mBC}$ & 113 & Paclitaxel plus bevacizumab & $\begin{array}{c}\text { SNPs of VEGF-A, VEGFR-2, IL-8, HIF-1 } \alpha, \\
\text { EPAS-1 and TSP-1 }\end{array}$ & $\begin{array}{l}\text { VEGFR-2 rs11133360 and IL-8 rs4073 genotypes were } \\
\text { significantly associated with PFS }\end{array}$ \\
\hline $\begin{array}{l}\text { Aravantinos G } \\
\text { et al. [50] }\end{array}$ & $\mathrm{mCRC}$ & 58 & $\begin{array}{l}\text { Irinotecan and fluoropyrimidines plus } \\
\text { bevacizumab }\end{array}$ & $\begin{array}{c}\text { CD133 rs3130 and rs2286455 } \\
\text { polymorphisms }\end{array}$ & $\begin{array}{l}\text { CD133 rs3130 C/C genotype was associated with } \\
\text { shorter OS }\end{array}$ \\
\hline $\begin{array}{l}\text { Di Salvatore M } \\
\text { et al. [37] }\end{array}$ & $\mathrm{mBC}$ & 31 & $\begin{array}{l}\text { Paclitaxel plus bevacizumab vs. paclitaxel } \\
\text { and carboplatin plus bevacizumab }\end{array}$ & $\begin{array}{l}\text { eNOS-894 G/T, eNOS-786 T/C, COX2-8473 } \\
\text { C/T, IL-8 251 T/A polymorphisms }\end{array}$ & $\begin{array}{c}\text { IL-8 rs } 4073 \mathrm{~T} / \mathrm{A} \text { and } e N O S \text { rs } 1799983 \mathrm{G} / \mathrm{T} \\
\text { polymorphisms were associated with improved PFS, } \\
\text { and PFS and OS respectively }\end{array}$ \\
\hline $\begin{array}{l}\text { Etienne-Grimaldi } \\
\text { MC et al. [34] }\end{array}$ & $\mathrm{mBC}$ & 137 & $\begin{array}{l}\text { Chemotherapy (paclitaxel, docetaxel, } \\
\text { vinorelbine, taxane combination, non-taxane } \\
\text { combination) plus bevacizumab }\end{array}$ & $\begin{array}{l}\text { VEGF-A polymorphisms in blood } \\
\text { samples }\end{array}$ & $\begin{array}{c}V E G F-A \text { rs2010963 C }>\mathrm{T} \text { polymorphism was associated } \\
\text { with longer time-to-progression }\end{array}$ \\
\hline $\begin{array}{l}\text { Formica V } \\
\text { et al. [44] }\end{array}$ & $\mathrm{mCRC}$ & 40 & FOLFIRI plus bevacizumab & $V E G F-A$ gene polymorphisms & $\begin{array}{l}V E G F-A \text { rs } 833061 \mathrm{G} / \mathrm{G} \text { and rs } 1570360 \mathrm{G} / \mathrm{G} \text { were } \\
\text { associated with shorter PFS, VEGF- } A \text { rs2010963 G/G } \\
\text { was associated with higher response rates }\end{array}$ \\
\hline $\begin{array}{l}\text { Galanis E } \\
\text { et al. [55] }\end{array}$ & Glioblastoma & 54 & Sorafenib plus bevacizumab & $\begin{array}{c}V E G F-A, V E G F R-2 \text { and } H I F-1 a \text { genes } \\
\text { polymorphisms }\end{array}$ & $\begin{array}{c}\text { Mutant } V E G F-A \text { rs699947, rs } 833061 \text { and heterozygous } \\
V E G F R-2 \text { rs2071559 were associated with increased } \\
\text { 6-month PFS success, but mutant } V E G F-A \text { rs1005230 } \\
\text { and rs1570360 were associated with decreased 6-month } \\
\text { PFS success }\end{array}$ \\
\hline $\begin{array}{l}\text { Gerger A } \\
\text { et al. [43] }\end{array}$ & $\mathrm{mCRC}$ & 132 & $\begin{array}{c}\text { Chemotherapy (FOLFOX, XELOX) plus } \\
\text { bevacizumab }\end{array}$ & $\begin{array}{c}\text { Comprehensive panel of } \\
\text { VEGF-dependent and } \\
\text { VEGF-independent angiogenesis genes } \\
\text { polymorphisms }\end{array}$ & $\begin{array}{c}E G F \text { rs444903 } \mathrm{A}>\mathrm{G} \text { and IGF-1 } \mathrm{rs} 6220 \mathrm{~A}>\mathrm{G} \text { were } \\
\text { associated with increased OS, CXCR1 rs2234671 } \mathrm{G}>\mathrm{C} \\
\text { was associated with higher response rates }\end{array}$ \\
\hline Hein A et al. [35] & $\mathrm{mBC}$ & 1454 & $\begin{array}{l}\text { Neoadjuvant epirubicin and } \\
\text { cyclophosphamide followed by docetaxel vs. } \\
\text { epirubicin and cyclophosphamide followed } \\
\text { by docetaxel plus bevacizumab }\end{array}$ & $\begin{array}{l}\text { SNPs in VEGF pathway genes in blood } \\
\text { samples }\end{array}$ & $\begin{array}{l}\text { VEGF-A rs833058, rs699947, rs3025039, rs3025030 and } \\
\text { VEGFR-1 rs79995976 were associated with higher rates } \\
\text { of pathological complete response, but they did not } \\
\text { remain significant after correction for multiple testing }\end{array}$ \\
\hline $\begin{array}{l}\text { Koutras A } \\
\text { et al. [46] }\end{array}$ & $\mathrm{mCRC}$ & 173 & $\begin{array}{c}\text { Chemotherapy (FOLFIRI, XELIRI) plus } \\
\text { bevacizumab }\end{array}$ & $\begin{array}{c}\text { SNPs of VEGF-A (rs1570360, rs699947, } \\
\text { rs2010963) }\end{array}$ & $\begin{array}{l}V E G F-A \text { rs } 1570360 \mathrm{G} / \mathrm{G} \text { was associated with no } \\
\text { response to treatment and inferior OS }\end{array}$ \\
\hline $\begin{array}{l}\text { Lambrechts D } \\
\text { et al. [54] }\end{array}$ & $\begin{array}{l}\text { Renal-cell } \\
\text { cancer }\end{array}$ & 649 & $\begin{array}{l}\text { Interferon alfa-2a plus bevacizumab vs. } \\
\text { interferon alfa-2a plus placebo }\end{array}$ & $\begin{array}{l}\text { Comprehensive panel of } \\
\text { VEGF-dependent angiogenesis genes } \\
\text { polymorphisms }\end{array}$ & $\begin{array}{l}\text { VEGFR-1 rs9582036 AA was associated with longer OS } \\
\text { and PFS in patients treated with bevacizumab }\end{array}$ \\
\hline $\begin{array}{l}\text { Loupakis F } \\
\text { et al. [40] }\end{array}$ & $\mathrm{mCRC}$ & 218 & FOLFIRI vs. FOLFIRI plus bevacizumab & $V E G F-A$ polymorphisms & $\begin{array}{c}\text { VEGF- } A \text { rs } 833061 \mathrm{C} / \mathrm{T} \text { polymorphism was significantly } \\
\text { associated with PFS and OS in patients treated } \\
\text { with bevacizumab }\end{array}$ \\
\hline $\begin{array}{l}\text { Loupakis F } \\
\text { et al. [41] }\end{array}$ & $\mathrm{mCRC}$ & 424 & FOLFIRI plus bevacizumab & SNPs of VEGF/VEGFR pathway & $\begin{array}{c}\text { VEGFR-2 rs12505758 T/T was associated with } \\
\text { improved PFS }\end{array}$ \\
\hline
\end{tabular}


Table 2. Cont.

\begin{tabular}{|c|c|c|c|c|c|}
\hline Reference & $\begin{array}{l}\text { Tumor } \\
\text { Type }\end{array}$ & $\begin{array}{l}\text { Number of } \\
\text { Patients }\end{array}$ & Treatment & Biomarkers & Findings \\
\hline $\begin{array}{l}\text { Matsusaka S } \\
\text { et al. [49] }\end{array}$ & $\mathrm{mCRC}$ & 511 & FOLFIRI plus bevacizumab & $\begin{array}{l}\text { IL-6 (rs2069837, rs1800795) and STAT3 } \\
\text { (rs744166, rs4796793) genes } \\
\text { polymorphisms }\end{array}$ & IL-6 rs2069837G was associated with longer PFS \\
\hline $\begin{array}{l}\text { Matsusaka S } \\
\text { et al. [51] }\end{array}$ & $\mathrm{mCRC}$ & 143 & $\begin{array}{c}\text { Chemotherapy (FOLFOX, XELOX) plus } \\
\text { bevacizumab }\end{array}$ & $\begin{array}{c}\text { SNPs in TWIST1 (rs2285682, rs2285681), } \\
\text { ZEB1 (rs10826943, rs2839658), SNAIL } \\
\text { (rs1543442, rs4647958), and E-cadherin } \\
\text { (rs16260) }\end{array}$ & $\begin{array}{l}\text { TWIST1 rs2285682 G allele was associated with longer } \\
\text { PFS and OS in patients treated with bevacizumab }\end{array}$ \\
\hline $\begin{array}{l}\text { Pallaud C } \\
\text { et al. [52] }\end{array}$ & NSCLC & 303 & $\begin{array}{l}\text { Chemotherapy (carboplatin plus paclitaxel } \\
\text { or carboplatin plus gemcitabine) plus } \\
\text { bevacizumab }\end{array}$ & $\begin{array}{l}V E G F-A, V E G F R-1 \text { and } V E G F R-2 \\
\text { polymorphisms }\end{array}$ & $\begin{array}{c}\text { VEGF-A rs699947 C }>\mathrm{A} \text { was associated with higher } \\
\text { response rate, rs } 2010963 \mathrm{C}>\mathrm{T} \text { was associated with } \\
\text { higher incidence of hypertension and } V E G F R-1 \\
\text { rs9554316 G/T was associated with higher risk of } \\
\text { progression and death }\end{array}$ \\
\hline $\begin{array}{l}\text { Papachristos A } \\
\text { et al. [38] }\end{array}$ & $\mathrm{mCRC}$ & 46 & $\begin{array}{l}\text { Chemotherapy (mFOLFOX6, FOLFIRI, } \\
\text { CapOX, CapIRI) plus bevacizumab }\end{array}$ & $\begin{array}{c}\text { VEGF-A (rs2010963, rs1570360, rs699947) } \\
\text { and ICAM-1(rs1799969, rs5498) } \\
\text { polymorphisms in blood and KRAS, } \\
\text { NRAS, BRAF mutations in tumor }\end{array}$ & $\begin{array}{l}\text { VEGF-A rs699947 A/A was associated with increased } \\
\text { PFS and OS, whereas ICAM-1 rs1799969 G/A and BRAF } \\
\text { wild-type were associated with prolonged OS }\end{array}$ \\
\hline Pohl A et al. [45] & $\mathrm{mCRC}$ & 91 & $\begin{array}{c}\text { Chemotherapy (FOLFOX, XELOX) plus } \\
\text { bevacizumab }\end{array}$ & $\begin{array}{l}\text { Intratumoral gene expression levels of } \\
\text { CD133, VEGF- } A \text { and } V E G F R \text { genes }\end{array}$ & $\begin{array}{l}\text { High gene expression of CD133 ( }>7.76) \text { was associated } \\
\text { with higher response rates and longer PFS }\end{array}$ \\
\hline $\begin{array}{l}\text { Schneider BP } \\
\text { et al. [33] }\end{array}$ & $\mathrm{mBC}$ & 363 & Paclitaxel vs. paclitaxel plus bevacizumab & $\begin{array}{l}V E G F-A \text { and } V E G F R-2 \text { polymorphisms } \\
\text { in tumor block samples }\end{array}$ & $\begin{array}{l}\text { VEGF-A rs699947 and rs } 1570360 \mathrm{~A} / \mathrm{A} \text { were associated } \\
\text { with significantly longer OS in patients treated with } \\
\text { bevacizumab }\end{array}$ \\
\hline $\begin{array}{l}\text { Schultheis, AM } \\
\text { et al. [53] }\end{array}$ & $\begin{array}{l}\text { Ovarian } \\
\text { cancer }\end{array}$ & 53 & Oral cyclophosphamide plus bevacizumab & $\begin{array}{c}\text { Comprehensive panel of } \\
\text { VEGF-dependent and } \\
\text { VEGF-independent angiogenesis genes } \\
\text { polymorphisms }\end{array}$ & $\begin{array}{l}\text { CXCR2 rs2230054 T/T was associated with lower PFS, } \\
\text { VEGF-A rs3025039 was associated with longer PFS, and } \\
I L-8 \text { A-251T was associated with higher response rates }\end{array}$ \\
\hline $\begin{array}{l}\text { Sohn BS } \\
\text { et al. [47] }\end{array}$ & $\mathrm{mCRC}$ & 125 & $\begin{array}{l}\text { Chemotherapy (mFOLFOX6, FOLFIRI, } \\
\text { CapOX, CapIRI) plus bevacizumab }\end{array}$ & $\begin{array}{l}\text { Polymorphisms in VEGF-A, FLT1, KDR, } \\
\text { IL-8, IL-10, CXCR2 and COL18A1 genes }\end{array}$ & $\begin{array}{l}V E G F-A \text { rs } 833061 \mathrm{~T} / \mathrm{T} \text { was associated with higher } \\
\text { response rates and } F L T 1 \text { rs } 9513070 \mathrm{~A} / \mathrm{A} \text { genotype was } \\
\text { associated with longer OS }\end{array}$ \\
\hline Ulivi P et al. [42] & $\mathrm{mCRC}$ & 237 & $\begin{array}{l}\text { Chemotherapy (FOLFOX4, FOLFIRI) vs. } \\
\text { chemotherapy (FOLFOX4, FOLFIRI) plus } \\
\text { bevacizumab }\end{array}$ & $\begin{array}{l}\text { VEGF- } A \text { (rs1570360, rs699947, rs2010963, } \\
\text { rs833061) and } e N O S(\mathrm{rs} 1799983 \\
\text { VNTR466) polymorphisms }\end{array}$ & $\begin{array}{c}\text { VEGF-A rs2010963 T/T and } e N O S \text { rs } 1799983 \mathrm{G} / \mathrm{T} \text { were } \\
\text { associated shorter PFS and OS, whereas } e N O S \text { VNTR466 } \\
\text { predisposed to longer PFS and OS in patients treated } \\
\text { with bevacizumab }\end{array}$ \\
\hline
\end{tabular}




\section{Bevacizumab Levels-Therapeutic Drug Monitoring (TDM)}

As already mentioned above an overall benefit of bevacizumab in the treatment of different tumors has been established. However, clinical outcomes can be highly variable, with some patients responding remarkably well, while others not. Another important parameter is side-effects such as hypertension, bleeding, phlebitis, embolism, and wound healing problems that often lead to delay or even permanent discontinuation of the treatment [56]. Thus, due to this heterogeneous response, the real clinical impact of bevacizumab remains unclear. A characteristic example is that it delays the progression of brain and breast cancers, it does not improve overall survival $[57,58]$. Pharmacokinetic parameters are among of the most important parameters, which influence drug action and clinical response. Monoclonal antibodies present very variable and complicated pharmacokinetics $[59,60]$. Thus, modulation of the pharmacokinetic parameters of bevacizumab could explain the inter-individual variability observed in patients. The mean half-life of bevacizumab is nearly 20 days [13], however, large individual differences were noted, with a range between 11 and 50 days. Presumably, this inter-individual variability could in some degree explain variable responses to the treatment. For example, when treatment is administered every two weeks, a patient for whom the half-life is 50 days would present an excess of circulating antibody from the second dose. This could result in side effects during therapy. In contrast, a patient for whom the half-life is only 11 days will rapidly clear bevacizumab, and this could impede treatment efficacy. Although these differences are remarkable and could impede treatment efficacy, a standardized administration protocol is recommended instead of a personalized treatment regimen. In order to implement more precise and personalized regimens based on bevacizumab pharmacokinetics and to develop therapeutic drug monitoring (TDM)-guided protocols, validated, fast and relatively cheap analytical techniques are needed.

In a non-oncology setting, TDM is a standard-of-care and cost-effective practice for several classes of antibiotics, immunosuppressants, antiepileptics, HIV agents, and many other drugs in clinical practice [61]. Moreover, the TDM-guided approach has been proved to improve safety and efficacy of both classic cytotoxic drugs as well as targeted therapies with small molecules tyrosine kinase inhibitors [62-68]. Similarly, there are some studies that support the TDM-approach for the treatment with monoclonal antibodies such as rituximab and cetuximab [69-71]. The progress in the field for bevacizumab includes the development of a validated ELISA method for levels measurements [72].

A recently published study assessed exposure-survival relationships in $46 \mathrm{mCRC}$ patients receiving bevacizumab in combination with chemotherapy as first-line treatment. They found a strong positive correlation between bevacizumab trough levels and survival $(p=0.0004)$. Furthermore, three distinct groups of exposure were identified. The low $(\leq 41.9 \mathrm{mg} / \mathrm{L})$ and medium $(43-87.2 \mathrm{mg} / \mathrm{L})$ groups with median OS of 12.8 and 36 months, respectively ( $p=0.0003)$; and high group ( $\geq 87.9 \mathrm{mg} / \mathrm{L}$ ), where the OS was not met as majority of patients were alive 60 months after the initiation of treatment. These findings suggest that bevacizumab trough concentration could be used both as a predictive biomarker of OS and as a tool to optimize treatment [73]. Nugue G et al. also analyzed bevacizumab concentrations in 17 breast cancer and glioblastoma patients throughout the first quarter of treatment. All of the patients were treated with bevacizumab $10 \mathrm{mg} / \mathrm{kg}$ every two weeks and blood samples were collected just before bevacizumab infusion. Average blood concentrations were $88 \mathrm{mg} / \mathrm{L}(54-149 \mathrm{mg} / \mathrm{L})$ and following the first dose and $213 \mathrm{mg} / \mathrm{L}(73-411 \mathrm{mg} / \mathrm{L}$ ) after the sixth dose administered. However, the individual values were scattered, with a mean four-fold difference between the lowest and the highest concentration for each dose administered. For the pharmacodynamic assessment, only 13 glioblastoma patients were used and breast cancer patients were excluded. Investigators classified patients in three groups according to clinical data: patients with side effects, non-responders, and good responders. Low serum bevacizumab concentrations were associated with a lack of efficacy, while high concentrations were associated with side effects. Thus, they concluded that serum bevacizumab concentration appears to be a useful clinical pharmacodynamic marker [74]. In 2016 two other groups published their results regarding the role of bevacizumab plasma concentrations. Firstly, in $20 \mathrm{mCRC}$ receiving bevacizumab and chemotherapy bevacizumab, not bevacizumab-bound VEGF, 
total VEGF, and Ang-2 plasma concentrations were determined. Blood collection was performed at baseline and immediately before the second and ifth cycles. Bevacizumab levels were quite similar immediately before the second cycle between all patients, measuring $2.61 \pm 1.10,5.51 \pm 5.28$ and $2.33 \pm 0.94 \mu \mathrm{g} / \mathrm{mL}$ in partial response (PR), stable disease (SD), and progression of disease (PD), respectively. However, drug levels change before the fifth cycle was different among patients with PR compared to those with SD and PD with a $0.72 \pm 0.25$ and $2.10 \pm 0.13$-fold increase, respectively. Moreover, assessment of VEGF as total and not bound before the second and fifth cycles revealed a significant decrease in the ratio of not bound to bevacizumab VEGF to total VEGF before the second and fifth cycles for patients who respond to treatment $(p<0.05)$ from $26.65 \%$ to $15.5 \%$ in PR group and from $53.41 \%$ to $34.95 \%$ in SD group. On the other hand, patients who showed a PD presented a significantly higher ratio $(p<0.05)$ before the second cycle, $51.71 \%$ vs. $25.99 \%$ [75]. A study by Caulet $\mathrm{M}$ et al. aimed to quantify individual factors affecting bevacizumab pharmacokinetics and assess the relationship between bevacizumab concentrations and clinical outcomes, concluding that decreased OS and PFS are associated with high bevacizumab concentration. In total, $137 \mathrm{mCRC}$ patients treated with bevacizumab and chemotherapy were included in the trial. Pharmacokinetics were assessed by using a two-compartment pharmacokinetic population model, OS, and PFS by using Cox models. According to the results, the volume of bevacizumab distribution was significantly increased with height $(p<0.0001)$ and was higher in patients carrying a $3 / 3$ variable number tandem repeat of the FCGRT gene $(p=0.039)$. Higher elimination rate was observed with increased baseline carcinoembryonic antigen (CEA) $(p=0.00029)$ and VEGF $(p=0.011)$ concentrations and was higher in patients with extra-hepatic metastases $(p=0.014)$. Moreover, the multivariate analysis showed that only baseline VEGF concentration and trough bevacizumab concentrations were independent risk factors for progression. Median PFS was 10.2 months and significant shorter when trough concentrations were $<15.5 \mathrm{mg} / \mathrm{L}$ compared to through concentrations $\geq 15.5 \mathrm{mg} / \mathrm{L}$ (8.7 vs. 13.6 months) [76].

\section{Conclusions}

As described above, several proteinic biomarkers and gene polymorphisms could be correlated with treatment outcomes. It is crucial to assess the replication of findings and focus on the significant findings identified by multiple studies in order to achieve better control of the false discovery rate. However, differences in tumor biology should be taken into account to interpret differences in results from different tumor types. Therefore, VEGF-A levels and VEGF-A rs699947 and rs1570360 are the most promising proteinic and genomic biomarkers, respectively, as they have been correlated with favorable clinical outcomes in several studies. Circulating VEGF-A levels could also be measured from a simple blood sample, and there are commercially available, standardized, validated ELISA kits, which can be easily added and applied at the point of care laboratories. Another fascinating and significant signal is the association of exposure to bevacizumab and survival, which could be used in order to develop TDM approaches.

The available data should be combined in order to optimize the treatment planning for each individual. As a result, a TDM and genetic biomarker-guided dose strategy appears feasible in the near future. In conclusion, barriers exist to the implementation of a personalized approach in bevacizumab treatment, but in the near future, this may feasibly improve quality of care and treatment outcomes.

Author Contributions: Conceptualization, A.P. and G.B.S.; methodology, A.P. and G.B.S.; writing-original draft preparation, A.P.; writing-review and editing, A.P. and G.B.S. All authors have read and agreed to the published version of the manuscript.

Funding: This research received no external funding.

Conflicts of Interest: The authors declare no conflict of interest. 


\section{References}

1. Folkman, J. Tumor angiogenesis: Therapeutic implications. N. Engl. J. Med. 1971, 285, 1182-1186.

2. Ellis, L.M.; Hicklin, D.J. VEGF-targeted therapy: Mechanisms of anti-tumour activity. Nat. Rev. Cancer 2008, 8, 579-591. [CrossRef]

3. Ferrara, N.; Gerber, H.-P.; LeCouter, J. The biology of VEGF and its receptors. Nat. Med. 2003, 9, 669-676. [CrossRef] [PubMed]

4. Hicklin, D.J.; Ellis, L.M. Role of the vascular endothelial growth factor pathway in tumor growth and angiogenesis. J. Clin. Oncol. 2005, 23, 1011-1027. [CrossRef] [PubMed]

5. Broll, R.; Erdmann, H.; Duchrow, M.; Oevermann, E.; Schwandner, O.; Markert, U.; Bruch, H.; Windhövel, U. Vascular endothelial growth factor (VEGF)-a valuable serum tumour marker in patients with colorectal cancer? Eur. J. Surg. Oncol. (EJSO) 2001, 27, 37-42. [CrossRef] [PubMed]

6. Werther, K.; Christensen, I.J.; Brünner, N.; Nielsen, H.J.; Group, D.R.C.C.S. Soluble vascular endothelial growth factor levels in patients with primary colorectal carcinoma. Eur. J. Surg. Oncol. (EJSO) 2000, 26, 657-662. [CrossRef] [PubMed]

7. Bremnes, R.M.; Camps, C.; Sirera, R. Angiogenesis in non-small cell lung cancer: The prognostic impact of neoangiogenesis and the cytokines VEGF and bFGF in tumours and blood. Lung Cancer 2006, 51, 143-158. [CrossRef]

8. Salgia, R. Prognostic significance of angiogenesis and angiogenic growth factors in nonsmall cell lung cancer. Cancer 2011, 117, 3889-3899. [CrossRef]

9. Karayiannakis, A.J.; Syrigos, K.N.; Polychronidis, A.; Zbar, A.; Kouraklis, G.; Simopoulos, C.; Karatzas, G. Circulating VEGF levels in the serum of gastric cancer patients: Correlation with pathological variables, patient survival, and tumor surgery. Ann. Surg. 2002, 236, 37. [CrossRef]

10. Karayiannakis, A.J.; Bolanaki, H.; Syrigos, K.N.; Asimakopoulos, B.; Polychronidis, A.; Anagnostoulis, S.; Simopoulos, C. Serum vascular endothelial growth factor levels in pancreatic cancer patients correlate with advanced and metastatic disease and poor prognosis. Cancer Lett. 2003, 194, 119-124. [CrossRef]

11. Gerber, H.-P.; Ferrara, N. Pharmacology and pharmacodynamics of bevacizumab as monotherapy or in combination with cytotoxic therapy in preclinical studies. Cancer Res. 2005, 65, 671-680.

12. EMA Summary of Product Characteristics. Available online: https://www.ema.europa.eu/en/documents/ product-information/avastin-epar-product-information_en.pdf (accessed on 20 March 2020).

13. FDA AVASTIN@Prescribing Information. Available online: https://www.accessdata.fda.gov/drugsatfda docs/label/2009/125085s0169lbl.pdf (accessed on 20 March 2020).

14. Haines, I.E.; Gabor Miklos, G.L. Bevacizumab Moonshots: An Important Outcome From the Latest Ovarian Cancer Mission. J. Clin. Oncol. 2019, 38, 171-172. [CrossRef]

15. Ocaña, A.; Amir, E.; Vera, F.; Eisenhauer, E.A.; Tannock, I.F. Addition of bevacizumab to chemotherapy for treatment of solid tumors: Similar results but different conclusions. J. Clin. Oncol. 2011, 29, 254-256. [CrossRef]

16. Sledge, G.W. Anti-Vascular Endothelial Growth Factor Therapy in Breast Cancer: Game Over? J. Clin. Oncol. 2015, 33, 133-135. [CrossRef]

17. Burstein, H.J.; Chen, Y.-H.; Parker, L.M.; Savoie, J.; Younger, J.; Kuter, I.; Ryan, P.D.; Garber, J.E.; Chen, H.; Campos, S.M. VEGF as a marker for outcome among advanced breast cancer patients receiving anti-VEGF therapy with bevacizumab and vinorelbine chemotherapy. Clin. Cancer Res. 2008, 14, 7871-7877. [CrossRef] [PubMed]

18. Jubb, A.M.; Miller, K.D.; Rugo, H.S.; Harris, A.L.; Chen, D.; Reimann, J.D.; Cobleigh, M.A.; Schmidt, M.; Langmuir, V.K.; Hillan, K.J. Impact of exploratory biomarkers on the treatment effect of bevacizumab in metastatic breast cancer. Clin. Cancer Res. 2011, 17, 372-381. [CrossRef] [PubMed]

19. Jubb, A.M.; Hurwitz, H.I.; Bai, W.; Holmgren, E.B.; Tobin, P.; Guerrero, A.S.; Kabbinavar, F.; Holden, S.N.; Novotny, W.F.; Frantz, G.D. Impact of vascular endothelial growth factor-A expression, thrombospondin-2 expression, and microvessel density on the treatment effect of bevacizumab in metastatic colorectal cancer. $J$. Clin. Oncol. 2006, 24, 217-227. [CrossRef] [PubMed]

20. Jürgensmeier, J.; Schmoll, H.; Robertson, J.; Brooks, L.; Taboada, M.; Morgan, S.; Wilson, D.; Hoff, P. Prognostic and predictive value of VEGF, sVEGFR-2 and CEA in mCRC studies comparing cediranib, bevacizumab and chemotherapy. Br. J. Cancer 2013, 108, 1316-1323. [CrossRef] 
21. Tsai, H.-L.; Lin, C.-H.; Huang, C.-W.; Yang, I.-P.; Yeh, Y.-S.; Hsu, W.-H.; Wu, J.-Y.; Kuo, C.-H.; Tseng, F.-Y.; Wang, J.-Y. Decreased peritherapeutic VEGF expression could be a predictor of responsiveness to first-line FOLFIRI plus bevacizumab in mCRC patients. Int. J. Clin. Exp. Pathol. 2015, 8, 1900.

22. Willett, C.G.; Duda, D.G.; Di Tomaso, E.; Boucher, Y.; Ancukiewicz, M.; Sahani, D.V.; Lahdenranta, J.; Chung, D.C.; Fischman, A.J.; Lauwers, G.Y. Efficacy, safety, and biomarkers of neoadjuvant bevacizumab, radiation therapy, and fluorouracil in rectal cancer: A multidisciplinary phase II study. J. Clin. Oncol. 2009, 27, 3020. [CrossRef]

23. Zhao, L.; Zhang, D.; Ma, H.; Jin, M.; Huang, F.; Zhang, T. High VEGF-A level at baseline predicts poor treatment effect of bevacizumab-based chemotherapy in metastatic colorectal cancer: A meta-analysis. Panminerva Med. 2016, 58, 48-58. [PubMed]

24. Kopetz, S.; Hoff, P.M.; Morris, J.S.; Wolff, R.A.; Eng, C.; Glover, K.Y.; Adinin, R.; Overman, M.J.; Valero, V.; Wen, S. Phase II trial of infusional fluorouracil, irinotecan, and bevacizumab for metastatic colorectal cancer: Efficacy and circulating angiogenic biomarkers associated with therapeutic resistance. J. Clin. Oncol. 2010, 28, 453. [CrossRef] [PubMed]

25. Ronzoni, M.; Manzoni, M.; Mariucci, S.; Loupakis, F.; Brugnatelli, S.; Bencardino, K.; Rovati, B.; Tinelli, C.; Falcone, A.; Villa, E. Circulating endothelial cells and endothelial progenitors as predictive markers of clinical response to bevacizumab-based first-line treatment in advanced colorectal cancer patients. Ann. Oncol. 2010, 21, 2382-2389. [CrossRef] [PubMed]

26. Yamamoto, Y.; Okamoto, W.; Makiyama, A.; Shitara, K.; Denda, T.; Ogura, T.; Nakano, Y.; Nishina, T.; Komoda, M.; Hara, H.; et al. Plasma ICAM-1 (pICAM-1) and plasma IL-8 (pIL-8) level as biomarker of metastatic colorectal cancer patients (mCRC) treated with mFOLFOX6/XELOX plus bevacizumab (BV) (WJOG7612GTR). J. Clin. Oncol. 2018, 36 (Suppl. 4), 670. [CrossRef]

27. Dowlati, A.; Gray, R.; Sandler, A.B.; Schiller, J.H.; Johnson, D.H. Cell adhesion molecules, vascular endothelial growth factor, and basic fibroblast growth factor in patients with non-small cell lung cancer treated with chemotherapy with or without bevacizumab-An eastern cooperative oncology group study. Clin. Cancer Res. 2008, 14, 1407-1412. [CrossRef]

28. Mok, T.; Gorbunova, V.; Juhasz, E.; Szima, B.; Burdaeva, O.; Orlov, S.; Yu, C.-J.; Archer, V.; Hilton, M.; Delmar, P. A Correlative Biomarker Analysis of the Combination of Bevacizumab and Carboplatin-Based Chemotherapy for Advanced Nonsquamous Non-Small-Cell Lung Cancer: Results of the Phase II Randomized ABIGAIL Study (BO21015). J. Thoracic Oncol. 2014, 9, 848-855. [CrossRef]

29. Horn, L.; Dahlberg, S.E.; Sandler, A.B.; Dowlati, A.; Moore, D.F.; Murren, J.R.; Schiller, J.H. Phase II study of cisplatin plus etoposide and bevacizumab for previously untreated, extensive-stage small-cell lung cancer: Eastern Cooperative Oncology Group Study E3501. J. Clin. Oncol. 2009, 27, 6006. [CrossRef]

30. Alvarez Secord, A.; Bell Burdett, K.; Owzar, K.; Tritchler, D.; Sibley, A.B.; Liu, Y.; Starr, M.D.; Brady, J.C.; Lankes, H.A.; Hurwitz, H.I.; et al. Predictive Blood-Based Biomarkers in Patients with Epithelial Ovarian Cancer Treated with Carboplatin and Paclitaxel with or without Bevacizumab: Results from GOG-0218. Clin. Cancer Res. 2020, 26, 1288-1296. [CrossRef]

31. Nixon, A.B.; Halabi, S.; Shterev, I.; Starr, M.; Brady, J.C.; Dutcher, J.P.; Hopkins, J.O.; Hurwitz, H.; Small, E.J.; Rini, B.I. Identification of predictive biomarkers of overall survival (OS) in patients (pts) with advanced renal cell carcinoma (RCC) treated with interferon alpha (I) with or without bevacizumab (B): Results from CALGB 90206 (Alliance). Am. Soc. Clin.Oncol. 2013, 31, 4520. [CrossRef]

32. Sathornsumetee, S.; Cao, Y.; Marcello, J.E.; Herndon, J.E. Tumor angiogenic and hypoxic profiles predict radiographic response and survival in malignant astrocytoma patients treated with bevacizumab and irinotecan. J. Clin. Oncol. Off. J. Am. Soc. Clin. Oncol. 2008, 26, 271. [CrossRef]

33. Schneider, B.P.; Wang, M.; Radovich, M.; Sledge, G.W.; Badve, S.; Thor, A.; Flockhart, D.A.; Hancock, B.; Davidson, N.; Gralow, J. Association of vascular endothelial growth factor and vascular endothelial growth factor receptor-2 genetic polymorphisms with outcome in a trial of paclitaxel compared with paclitaxel plus bevacizumab in advanced breast cancer: ECOG 2100. J. Clin. Oncol. 2008, 26, 4672. [CrossRef] [PubMed]

34. Etienne-Grimaldi, M.C.; Formento, P.; Degeorges, A.; Pierga, J.Y.; Delva, R.; Pivot, X.; Dalenc, F.; Espié, M.; Veyret, C.; Formento, J.L. Prospective analysis of the impact of VEGF-A gene polymorphisms on the pharmacodynamics of bevacizumab-based therapy in metastatic breast cancer patients. Br. J. Clin. Pharmacol. 2011, 71, 921-928. [CrossRef] [PubMed] 
35. Hein, A.; Lambrechts, D.; von Minckwitz, G.; Haberle, L.; Eidtmann, H.; Tesch, H.; Untch, M.; Hilfrich, J.; Schem, C.; Rezai, M.; et al. Genetic variants in VEGF pathway genes in neoadjuvant breast cancer patients receiving bevacizumab: Results from the randomized phase III GeparQuinto study. Int. J. Cancer 2015, 137, 2981-2988. [CrossRef] [PubMed]

36. Allegrini, G.; Coltelli, L.; Orlandi, P.; Fontana, A.; Camerini, A.; Ferro, A.; Cazzaniga, M.; Casadei, V.; Lucchesi, S.; Bona, E.; et al. Pharmacogenetic interaction analysis of VEGFR-2 and IL-8 polymorphisms in advanced breast cancer patients treated with paclitaxel and bevacizumab. Pharmacogenomics 2014, 15, 1985-1999. [CrossRef]

37. Di Salvatore, M.; Lo Giudice, L.; Rossi, E.; Santonocito, C.; Nazzicone, G.; Rodriquenz, M.G.; Cappuccio, S.; Inno, A.; Fuso, P.; Orlandi, A.; et al. Association of IL-8 and eNOS polymorphisms with clinical outcomes in bevacizumab-treated breast cancer patients: An exploratory analysis. Clin. Transl. Oncol. 2016, 18, 40-46. [CrossRef]

38. Papachristos, A.; Kemos, P.; Katsila, T.; Panoilia, E.; Patrinos, G.P.; Kalofonos, H.; Sivolapenko, G.B. VEGF-A and ICAM-1 Gene Polymorphisms as Predictors of Clinical Outcome to First-Line Bevacizumab-Based Treatment in Metastatic Colorectal Cancer. Int. J. Mol. Sci. 2019, 20, 5791. [CrossRef]

39. Papachristos, A.; Karatza, E.; Kalofonos, H.; Sivolapenko, G. Pharmacogenetics in Model-Based Optimization of Bevacizumab Therapy for Metastatic Colorectal Cancer. Int. J. Mol. Sci. 2020, 21, 3753. [CrossRef]

40. Loupakis, F.; Ruzzo, A.; Salvatore, L.; Cremolini, C.; Masi, G.; Frumento, P.; Schirripa, M.; Catalano, V.; Galluccio, N.; Canestrari, E.; et al. Retrospective exploratory analysis of VEGF polymorphisms in the prediction of benefit from first-line FOLFIRI plus bevacizumab in metastatic colorectal cancer. BMC Cancer 2011, 11, 247. [CrossRef]

41. Loupakis, F.; Cremolini, C.; Yang, D.; Salvatore, L.; Zhang, W.; Wakatsuki, T.; Bohanes, P.; Schirripa, M.; Benhaim, L.; Lonardi, S.; et al. Prospective validation of candidate SNPs of VEGF/VEGFR pathway in metastatic colorectal cancer patients treated with first-line FOLFIRI plus bevacizumab. PLoS ONE 2013,8, e66774. [CrossRef]

42. Ulivi, P.; Scarpi, E.; Passardi, A.; Marisi, G.; Calistri, D.; Zoli, W.; Del Re, M.; Frassineti, G.L.; Tassinari, D.; Tamberi, S.; et al. eNOS polymorphisms as predictors of efficacy of bevacizumab-based chemotherapy in metastatic colorectal cancer: Data from a randomized clinical trial. J. Transl. Med. 2015, 13, 258. [CrossRef]

43. Gerger, A.; El-Khoueiry, A.; Zhang, W.; Yang, D.; Singh, H.; Bohanes, P.; Ning, Y.; Winder, T.; Labonte, M.J.; Wilson, P.M.; et al. Pharmacogenetic angiogenesis profiling for first-line Bevacizumab plus oxaliplatin-based chemotherapy in patients with metastatic colorectal cancer. Clin. Cancer Res. 2011, 17, 5783-5792. [CrossRef] [PubMed]

44. Formica, V.; Palmirotta, R.; Del Monte, G.; Savonarola, A.; Ludovici, G.; De Marchis, M.L.; Grenga, I.; Schirru, M.; Guadagni, F.; Roselli, M. Predictive value of VEGF gene polymorphisms for metastatic colorectal cancer patients receiving first-line treatment including fluorouracil, irinotecan, and bevacizumab. Int. J. Colorectal Dis. 2011, 26, 143-151. [CrossRef] [PubMed]

45. Pohl, A.; El-Khoueiry, A.; Yang, D.; Zhang, W.; Lurje, G.; Ning, Y.; Winder, T.; Hu-Lieskoven, S.; Iqbal, S.; Danenberg, K.D.; et al. Pharmacogenetic profiling of CD133 is associated with response rate (RR) and progression-free survival (PFS) in patients with metastatic colorectal cancer (mCRC), treated with bevacizumab-based chemotherapy. Pharm. J. 2013, 13, 173-180. [CrossRef] [PubMed]

46. Koutras, A.K.; Antonacopoulou, A.G.; Eleftheraki, A.G.; Dimitrakopoulos, F.I.; Koumarianou, A.; Varthalitis, I.; Fostira, F.; Sgouros, J.; Briasoulis, E.; Bournakis, E.; et al. Vascular endothelial growth factor polymorphisms and clinical outcome in colorectal cancer patients treated with irinotecan-based chemotherapy and bevacizumab. Pharm. J. 2012, 12, 468-475. [CrossRef] [PubMed]

47. Sohn, B.S.; Park, S.J.; Kim, J.E.; Kim, K.P.; Hong, Y.S.; Suh, C.; Kim, Y.S.; Kim, S.Y.; Im, S.A.; Kim, S.Y.; et al. Single-nucleotide polymorphisms in the vascular endothelial growth factor pathway and outcomes of patients treated with first-line cytotoxic chemotherapy combined with bevacizumab for advanced colorectal cancer. Oncology 2014, 87, 280-292. [CrossRef]

48. Eng, L.; Azad, A.K.; Habbous, S.; Pang, V.; Xu, W.; Maitland-van der Zee, A.H.; Savas, S.; Mackay, H.J.; Amir, E.; $\mathrm{Liu}, \mathrm{G}$. Vascular endothelial growth factor pathway polymorphisms as prognostic and pharmacogenetic factors in cancer: A systematic review and meta-analysis. Clin. Cancer Res. 2012, 18, 4526-4537. [CrossRef] 
49. Matsusaka, S.; Hanna, D.L.; Cao, S.; Zhang, W.; Yang, D.; Ning, Y.; Sunakawa, Y.; Okazaki, S.; Berger, M.D.; Miyamato, Y.; et al. Prognostic Impact of IL6 Genetic Variants in Patients with Metastatic Colorectal Cancer Treated with Bevacizumab-Based Chemotherapy. Clin. Cancer Res. 2016, 22, 3218-3226. [CrossRef]

50. Aravantinos, G.; Isaakidou, A.; Karantanos, T.; Sioziou, A.; Theodoropoulos, G.E.; Pektasides, D.; Gazouli, M. Association of CD133 polymorphisms and response to bevacizumab in patients with metastatic colorectal cancer. Cancer Biomark. 2015, 15, 843-850. [CrossRef]

51. Matsusaka, S.; Zhang, W.; Cao, S.; Hanna, D.L.; Sunakawa, Y.; Sebio, A.; Ueno, M.; Yang, D.; Ning, Y.; Parekh, A.; et al. TWIST1 Polymorphisms Predict Survival in Patients with Metastatic Colorectal Cancer Receiving First-Line Bevacizumab plus Oxaliplatin-Based Chemotherapy. Mol. Cancer Ther. 2016, 15, 1405-1411. [CrossRef]

52. Pallaud, C.; Reck, M.; Juhasz, E.; Szima, B.; Yu, C.J.; Burdaeva, O.; Orlov, S.; Hilton, M.; Archer, V.; Mok, T. Clinical genotyping and efficacy outcomes: Exploratory biomarker data from the phase II ABIGAIL study of first-line bevacizumab plus chemotherapy in non-squamous non-small-cell lung cancer. Lung Cancer 2014, 86, 67-72. [CrossRef]

53. Schultheis, A.M.; Lurje, G.; Rhodes, K.E.; Zhang, W.; Yang, D.; Garcia, A.A.; Morgan, R.; Gandara, D.; Scudder, S.; Oza, A. Polymorphisms and clinical outcome in recurrent ovarian cancer treated with cyclophosphamide and bevacizumab. Clin. Cancer Res. 2008, 14, 7554-7563. [CrossRef] [PubMed]

54. Lambrechts, D.; Claes, B.; Delmar, P.; Reumers, J.; Mazzone, M.; Yesilyurt, B.T.; Devlieger, R.; Verslype, C.; Tejpar, S.; Wildiers, H.; et al. VEGF pathway genetic variants as biomarkers of treatment outcome with bevacizumab: An analysis of data from the AViTA and AVOREN randomised trials. Lancet Oncol. 2012, 13, 724-733. [CrossRef]

55. Galanis, E.; Anderson, S.K.; Lafky, J.M.; Uhm, J.H.; Giannini, C.; Kumar, S.K.; Kimlinger, T.K.; Northfelt, D.W.; Flynn, P.J.; Jaeckle, K.A.; et al. Phase II study of bevacizumab in combination with sorafenib in recurrent glioblastoma (N0776): A north central cancer treatment group trial. Clin. Cancer Res. 2013, 19, 4816-4823. [CrossRef]

56. Ranpura, V.; Hapani, S.; Wu, S. Treatment-related mortality with bevacizumab in cancer patients: A meta-analysis. JAMA 2011, 305, 487-494. [CrossRef] [PubMed]

57. Miles, D.W.; Chan, A.; Dirix, L.Y.; Cortes, J.; Pivot, X.; Tomczak, P.; Delozier, T.; Sohn, J.H.; Provencher, L.; Puglisi, F.; et al. Phase III study of bevacizumab plus docetaxel compared with placebo plus docetaxel for the first-line treatment of human epidermal growth factor receptor 2-negative metastatic breast cancer. J. Clin. Oncol. 2010, 28, 3239-3247. [CrossRef]

58. Reardon, D.A.; Desjardins, A.; Peters, K.B.; Gururangan, S.; Sampson, J.H.; McLendon, R.E.; Herndon, J.E., 2nd; Bulusu, A.; Threatt, S.; Friedman, A.H.; et al. Phase II study of carboplatin, irinotecan, and bevacizumab for bevacizumab naive, recurrent glioblastoma. J. Neurooncol. 2012, 107, 155-164. [CrossRef]

59. Mould, D.R.; Green, B. Pharmacokinetics and pharmacodynamics of monoclonal antibodies: Concepts and lessons for drug development. BioDrugs 2010, 24, 23-39. [CrossRef]

60. Ordas, I.; Mould, D.R.; Feagan, B.G.; Sandborn, W.J. Anti-TNF monoclonal antibodies in inflammatory bowel disease: Pharmacokinetics-based dosing paradigms. Clin. Pharmacol. Ther. 2012, 91, 635-646. [CrossRef]

61. Touw, D.J.; Neef, C.; Thomson, A.H.; Vinks, A.A. Cost-effectiveness of therapeutic drug monitoring: A systematic review. Ther. Drug Monit. 2005, 27, 10-17. [CrossRef]

62. Gao, B.; Yeap, S.; Clements, A.; Balakrishnar, B.; Wong, M.; Gurney, H. Evidence for therapeutic drug monitoring of targeted anticancer therapies. J. Clin. Oncol. 2012, 30, 4017-4025. [CrossRef]

63. Gotta, V.; Widmer, N.; Decosterd, L.A.; Chalandon, Y.; Heim, D.; Gregor, M.; Benz, R.; Leoncini-Franscini, L.; Baerlocher, G.M.; Duchosal, M.A.; et al. Clinical usefulness of therapeutic concentration monitoring for imatinib dosage individualization: Results from a randomized controlled trial. Cancer Chemother. Pharmacol. 2014, 74, 1307-1319. [CrossRef] [PubMed]

64. Paci, A.; Veal, G.; Bardin, C.; Leveque, D.; Widmer, N.; Beijnen, J.; Astier, A.; Chatelut, E. Review of therapeutic drug monitoring of anticancer drugs part 1-cytotoxics. Eur. J. Cancer 2014, 50, 2010-2019. [CrossRef] [PubMed]

65. Patel, J.N.; O’Neil, B.H.; Deal, A.M.; Ibrahim, J.G.; Sherrill, G.B.; Olajide, O.A.; Atluri, P.M.; Inzerillo, J.J.; Chay, C.H.; McLeod, H.L.; et al. A community-based multicenter trial of pharmacokinetically guided 5-fluorouracil dosing for personalized colorectal cancer therapy. Oncologist 2014, 19, 959-965. [CrossRef] [PubMed] 
66. Patel, J.N.; Papachristos, A. Personalizing chemotherapy dosing using pharmacological methods. Cancer Chemother. Pharmacol. 2015, 76, 879-896. [CrossRef]

67. Widmer, N.; Bardin, C.; Chatelut, E.; Paci, A.; Beijnen, J.; Leveque, D.; Veal, G.; Astier, A. Review of therapeutic drug monitoring of anticancer drugs part two-targeted therapies. Eur. J. Cancer 2014, 50, 2020-2036. [CrossRef]

68. Yu, H.; Steeghs, N.; Nijenhuis, C.M.; Schellens, J.H.; Beijnen, J.H.; Huitema, A.D. Practical guidelines for therapeutic drug monitoring of anticancer tyrosine kinase inhibitors: Focus on the pharmacokinetic targets. Clin. Pharm. 2014, 53, 305-325. [CrossRef]

69. Berinstein, N.L.; Grillo-Lopez, A.J.; White, C.A.; Bence-Bruckler, I.; Maloney, D.; Czuczman, M.; Green, D.; Rosenberg, J.; McLaughlin, P.; Shen, D. Association of serum Rituximab (IDEC-C2B8) concentration and anti-tumor response in the treatment of recurrent low-grade or follicular non-Hodgkin's lymphoma. Ann. Oncol. 1998, 9, 995-1001. [CrossRef]

70. Fracasso, P.M.; Burris, H., 3rd; Arquette, M.A.; Govindan, R.; Gao, F.; Wright, L.P.; Goodner, S.A.; Greco, F.A.; Jones, S.F.; Willcut, N.; et al. A phase 1 escalating single-dose and weekly fixed-dose study of cetuximab: Pharmacokinetic and pharmacodynamic rationale for dosing. Clin. Cancer Res. 2007, 13, 986-993. [CrossRef]

71. McLaughlin, P.; Grillo-Lopez, A.J.; Link, B.K.; Levy, R.; Czuczman, M.S.; Williams, M.E.; Heyman, M.R.; Bence-Bruckler, I.; White, C.A.; Cabanillas, F.; et al. Rituximab chimeric anti-CD20 monoclonal antibody therapy for relapsed indolent lymphoma: Half of patients respond to a four-dose treatment program. J. Clin. Oncol. 1998, 16, 2825-2833. [CrossRef]

72. Ternant, D.; Ceze, N.; Lecomte, T.; Degenne, D.; Duveau, A.C.; Watier, H.; Dorval, E.; Paintaud, G. An enzyme-linked immunosorbent assay to study bevacizumab pharmacokinetics. Ther. Drug Monit. 2010, 32, 647-652. [CrossRef]

73. Papachristos, A.; Kemos, P.; Kalofonos, H.; Sivolapenko, G. Correlation Between Bevacizumab Exposure and Survival in Patients with Metastatic Colorectal Cancer. Oncologist 2020. [CrossRef] [PubMed]

74. Nugue, G.; Bidart, M.; Arlotto, M.; Mousseau, M.; Berger, F.; Pelletier, L. Monitoring monoclonal antibody delivery in oncology: The example of bevacizumab. PLoS ONE 2013, 8, e72021. [CrossRef] [PubMed]

75. Azzariti, A.; Porcelli, L.; Brunetti, O.; Del Re, M.; Longo, V.; Nardulli, P.; Signorile, M.; Xu, J.M.; Calabrese, A.; Quatrale, A.E.; et al. Total and not bevacizumab-bound vascular endothelial growth factor as potential predictive factors to bevacizumab-based chemotherapy in colorectal cancer. World J. Gastroenterol. 2016, 22, 6287-6295. [CrossRef] [PubMed]

76. Caulet, M.; Lecomte, T.; Bouche, O.; Rollin, J.; Gouilleux-Gruart, V.; Azzopardi, N.; Leger, J.; Borg, C.; Douillard, J.Y.; Manfredi, S.; et al. Bevacizumab Pharmacokinetics Influence Overall and Progression-Free Survival in Metastatic Colorectal Cancer Patients. Clin. Pharm. 2016, 55, 1381-1394. [CrossRef] [PubMed]

(C) 2020 by the authors. Licensee MDPI, Basel, Switzerland. This article is an open access article distributed under the terms and conditions of the Creative Commons Attribution (CC BY) license (http://creativecommons.org/licenses/by/4.0/). 